Brit. F. vener. Dis. (1973) 49, 478

\title{
Gonorrhoea and condyloma acuminata in a male transsexual
}

\author{
N. J. FIUMARA* AND ARTHUR DI MATTIA† \\ Department of Dermatology and Syphilology, Boston City Hospital
}

The relative frequency of surgical sex reassignment of the male transsexual has prompted questions as to 'her' susceptibility to infections with gonorrhoea and the symptomatology and management of this infection in such patients. We have been unable to find any previous record of such a case and for this reason the present report may be of interest.

\section{Case report}

A 25-year-old male transsexual had genital reconstructive surgery in April, 1972, in New York City, and came to the clinic on October 16,1972, because of a 'vaginal' discharge and dysuria of 1 week's duration. She also complained of a number of painless lumps on the labia which she feared might be syphilitic. She worked as an ecdysiast (stripper) in a night club and formerly as a prostitute, but now only with selected clientèle.

\section{Examination and management}

She appeared to be a beautiful female with soft, white, non-hairy skin, well-developed breasts (the result of silicone injections and oestrogen), male pattern pubic hair which she shaved regularly, and reconstructed external organs of female appearance.

There was a purulent urethral discharge and a number of papules with digitating surfaces on the labia and in the vagina; the latter extended a good $2^{\prime \prime}$ in depth. A specimen of pus for smear and culture on Thayer-Martin medium was taken from the urethra. The smear showed presumed gonococci; the patient (who was sensitive to penicillin) was treated with $2 \mathrm{~g}$. spectinomycin intramuscularly. The culture was overgrown with $B$. proteus. A blood test for syphilis was non-reactive.

*Director, Division of Communicable Diseases, Massachusetts Department of Public Health; clinical professor of dermatology and preventive medicine, Boston University School of Medicine; lecturer in dermatology and syphilology, Tufts University School of Medicine; instructor in dermatology, Harvard Medical School; clinical associate in dermatology, Massachusetts General Hospital; visiting physician, University Hospital; associate physician for dermatology, Boston City Hospital; physician, Department of Dermatology and Syphilology, Boston Dispensary.

$\nmid$ Resident in Dermatology, Boston City Hospital

Received for publication November 11, 1972
The condyloma acuminata were successfully treated with 20 per cent. podophyllin in tincture of benzoin.

\section{Comment}

In determining the sex of an individual, four anatomical criteria are used: chromosome complement, anatomy of the gonad, anatomy of the external genitalia, and anatomy of the internal genitalia (Jones, Money, and Meyer (1972). It is the practice to designate the sex of an individual according to the gonads, a male having testes, and a female ovaries.

A male transsexual has a testis but aspires to and assumes the female sex and considers herself as a female in social behaviour. The individual has a consistent and persistent desire to live as a female and takes progressive steps to do so (Money and Gaskin, 1970-71). Our patient lived as a female for 5 years before her operation, and regarded herself as a female trapped within a male body.

The true male transsexual exhibits many aspects of female personality. She dresses in feminine clothing, avoids the activities considered by society to be typically male, and above all wants to get rid of the penis, which is a constant reminder and symbol of a sexual status that is regarded as false and repulsive. Wanting a body which looks like that of a female, she will seek to have a vagina constructed by surgery, and breasts enlarged by silicone gel injections or implants; facial and other hairs are removed by electrolysis; a feminine contour of hips and face are obtained by surgery or silicone gel injections; and the general effect is enhanced by hormonal therapy with oestrogens.

Genital reconstructive surgery may be a one-stage (as in our patient) or a two-stage procedure (Jones, Schirmer, and Hoopes, 1968). The one-stage procedure uses the available tissue of the penis and scrotum to form the lining of the vaginal cavity. The two-stage operation removes the corpora of the penis and testes in the first phase, using the skin of 
the penis and scrotum to form the external genitalia; the second-stage is confined to constructing a vagina by using a split-thickness graft to line the vaginal cavity. By either method, the vagina is lined with stratified squamous epithelium which is resistant to infection with gonorrhoea (Fiumara, 1972). Gonococcal infection must be looked for in the urethra and specimens for laboratory examination must be taken from this site.

\section{Summary and conclusions}

A male transsexual, who was legally declared to be a female by court decree after genital reconstructive surgery, was found to have gonococcal urethritis and also condyloma acuminata involving the labia and vagina. Gonococcal infection in such cases will be limited to the urethra and will not affect the vagina. Male transsexual operations, while still few, make it necessary for the venereologist to be aware of the possibility of sexually transmitted diseases in such cases. Two diseases coexisted in our patient.

If, as our patient revealed, many male transsexuals are working as strippers with a secondary occupation, the venereologist may have ample opportunity to study the epidemiology of the sexually transmissible diseases in such patients.

\section{References}

Fiumara, N. J. (1972) Med. Clin. N. Amer., 56, 1105 JoNes, H. W., JR., MONEY, J., and MEYER, J. K. (1972)

'An appraisal of the role of the gynecologist in the treatment of male transsexualism', in 'Year Book of Obstetrics and Gynecology, 1972', pp. 276-284. Year Book Medical Publishers, Chicago

- SChIRMer, H. K. A., and Hoopes, J. E. (1968) Amer. F. Obstet. Gynec., 100, 101

Money, J., and Gaskin, R. J. (1970-71) Int. F. Psychiat., 9, 249

Gonococcie et végétations vénériennes chez un sujet masculin transsexué

\section{SOMMAIRE}

Chez un sujet masculin transsexué, qui, après chirurgie réparatrice génitale, fut légalement déclaré comme femme par décret de justice, on a trouvé une urétrite gonococcique ainsi que des végétations vénériennes développées sur les lèvres et le vagin. Dans de tels cas, l'infection gonococcique se limitera à l'urètre sans toucher le vagin. La pratique d'interventions chez des sujets masculins transsexués, bien que celles-ci soient rares, oblige le vénéréologue à connaître dans de tels cas la possibilité de maladies transmises par voie sexuelle. Deux maladies coexistaient chez notre malade.

$\mathrm{Si}$, comme notre malade nous l'a révélé, beaucoup d'hommes transsexués travaillent comme 'strippers'^, à côté d'une occupation secondaire, le vénéréologue peut avoir de nombreuses occasions d'étudier l'épidémiologie des maladies transmises par voie sexuelle chez de tels malades.

* de strip-tease (NDT). 